Available online at http://jurnal.goretanpena.com/index.php/JSSR

\title{
PENERAPAN METODE CUSTOMER RELATIONSHIP MANAGEMENT PADA PENJUALAN TOKO BAJU AZZAHRA
}

\author{
Irianto $^{1}$, Sudarmin $^{2}$, Afrisawati $^{3}$ \\ STMIK Royal, Kisaran \\ e-mail: ${ }^{1}$ irianto2121212@gmail.com
}

\begin{abstract}
System analysis is an activity to describe a complete and real information system into components that aim to identify and evaluate problems that arise, thus leading to a solution for improvement and development in a better direction and according to needs. The use of the old system to promote products in the form of clothing that currently exists does not meet the standards of technological developments at this time, because the existing system is still carried out using a manual form that will be recorded, so that in processing the data it takes a little time, resulting in the presentation of sales reports being slow For the current flow and system in terms of the process of selling clothes at azzahra clothes shop, it is described using Use Case Diagrams, Class Diagrams, Sequence Diagrams, Activity Diagrams and Deployment Diagrams.
\end{abstract}

Keywords: CRM; Customer satisfaction; Sales Strategy.

Abstrak: Analisis sistem merupakan kegiatan menguraikan suatu sistem informasi yang utuh dan nyata kedalam komponen yang bertujuan untuk mengidentifikasi serta mengevaluasi masalah-masalah yang muncul, sehingga mengarah kepada suatu solusi untuk perbaikan maupun pengembangan ke arah yang lebih baik dan sesuai dengan kebutuhan. Penggunaan sistem lama untuk mempromosikan produk berupa baju yang ada sekarang ini belum memenuhi standar perkembangan teknologi dimasa ini, dikarenakan sistem yang ada masih dilakukan menggunakan bentuk manual yang akan dibuat pembukuannya, sehingga dalam pengolahan datanya sedikit memakan waktu sehingga mengakibatkan penyajian laporan penjualan menjadi lambat. Untuk alur dan sistem yang sedang berjalan dalam hal proses penjualan pakaian pada toko baju azzahra diuraikan menggunakan Use Case Diagram, Class Diagram, Sequence Diagram, Activity Diagram dan Deployment Diagram.

Kata kunci: CRM; Kepuasan Pelanggan; Strategi Penjualan.

\section{PENDAHULUAN}

Kemajuan teknologi informasi yang pesat sesuai dengan kebutuhan hampir disetiap aspek kehidupan. Saat ini sudah bukan rahasia lagi bahwa teknologi informasi dapat memberi kemudahan dalam mencari informasi yang diinginkan, mengurangi terjadinya kesalahan yang disebabkan oleh kelalaian manusia dan penggunaan data yang lebih efisien. Penggunaan teknologi informasi yang optimal dalam sebuah perusahaan akan menunjang efisiensi dan efektifitas kerja dalam mengolah data untuk mendapatkan informasi yang dibutuhkan.

Customer Relationship Management (CRM) adalah strategi tingkat korporasi yang berfokus pada pembangunan dan pemeliharaan hubungan dengan pelanggan. (Ratnasari et al., 2021)

Begitu juga dengan E-Commerce, E-Commerce merupakan penjualan atau pembelian jasa atau barang antara perusahaan, rumah tangga, individu, pemerintah, masyarakat, atau organisasi swasta lainnya, yang dilakukan melalui 
Available online at http://jurnal.goretanpena.com/index.php/JSSR

komputer pada media jaringan. (Guntur \& Djasuro, 2017)

Informasi adalah data yang diolah menjadi bentuk yang berguna untuk membuat keputusan. Informasi berguna dan lebih berarti bagi yang menerimah nya.(Sholihah \& Fahrullah, 2020)

Apalagi saat ini kemajuan teknologi informasi itu sendiri di dukung oleh hadirnya internet yang perkembangannya berkembang sangat pesat, karena hampir semua orang diseluruh dunia menggunakan internet. Internet merupakan tempat terhubungnya berbagai mesin komputer yang mengolah informasi di dunia ini, dengan internet maka akan didapat jutaan informasi, mulai dari informasi kota-kota dunia, pemerintahan, budaya, teknologi, berita majalah dan Koran dari seluruh dunia, bahkan kita dapat berbisnis melalui internet. (Riris Roisah et al., 2019)

Toko Baju Azzahra merupakan salah satu bentuk usaha penjualan pakaian yang berada di Kecamatan Sei Dadap. Dalam proses penjualan, promosi produk pada Toko Baju Azzahra ini masih dilakukan secara manual, yaitu dengan menggunakan alat tulis seperti buku, pena dan lain sebagainya yang membuat data yang dihasilkan mudah robek, terbakar, basah dan sebagainya. Hal ini terjadi dikarenakan pada Toko Baju Azzahra belum terdapat suatu sistem penjualan yang berbasis online, sehingga nantinya banyak orang diluar sana dapat lebih paham dan mengerti serta mengetahui terkait kualitas, jumlah produk yang dijual pada Toko Baju Azzahra. Apabila hal ini terus dibiarkan, maka tingkat kemajuan Toko Baju Azzahra akan kalah dengan kompetitor lainnya yang sejenis. Pengaruh yang besar akan didapat jika memiliki suatu sistem informasi berbasis $w e b$ dalam hal penjualan tentunya.

Dari adanya permasalahan di atas penulis ingin membuat suatu sistem informasi berbasis web dengan bantuan program aplikasi $P H P$ dan $M y S Q L$ dengan metode Customer Relationship
Management (CRM) yang akan membantu Toko Baju Azzahra dalam memperkenalkan dan mempromosikan produknya.

\section{METODE}

\section{Sistem Informasi}

Menurut "Sistem informasi adalah kerangka kerja yang mengkoordinasikan sumber daya (manusia, komputer) untuk mengubah masukan (input) menjadi keluaran (informasi), guna mencapai sasaransasaran perusahaan(Emaluta et al., 2019).

Sistem informasi adalah suatu sistem di dalam suatu organisasi yang mempertemukan kebutuhan pengolahan transaksi harian yang mendukung fungsi operasi organisasi yang bersifat manajerial dengan kegiatan strategi dari suatu organisasi untuk dapat menyediakan kepada pihak luar tertentu dengan laporan-laporan yang diperlukan (Middleton, 2019)

Dari beberapa pengertian di atas dapat disimpulkan bahwa sistem informasi adalah suatu kerangka kerja yang mendukung fungsi operasi dalam organisasi sehingga berguna demi tercapainya tujuan-tujuan perusahaan.

\section{Komponen Sistem Informasi}

Sistem informasi mendukung komponen-komponen sebagai berikut (Yuniar \& Handriani, 2020):

1. Perangkat Keras (Hardware) Mencakup piranti-piranti fisik seperti komputer dan printer.

2. Perangkat Lunak (Software)

Sekumpulan instruksi yang memungkinkan perangkat keras memproses data.

3. Prosedur

Sekumpulan aturan yang dipakai untuk mewujudkan pemrosesan data dan pembangkitan keluaran yang dikehendaki.

4. Orang

Semua pihak yang bertanggung jawab dalam pengembangan sistem 
Available online at http://jurnal.goretanpena.com/index.php/JSSR

informasi, pemrosesan, dan penggunaan keluaran sistem informasi.

5. Basis Data (Database)

Kumpulan tabel, hubungan, dan lainlain yang berkaitan dengan penyimpanan data.

6. Jaringan Komputer dan Komunikasi Data

Sistem penghubung yang memungkinkan sumber (resources) dipakai secara bersama atau diakses oleh sejumlah pemakai.

\section{Siklus Sistem Informasi}

Siklus sistem informasi disebut siklus makro, dimana siklus sistem basis data dirujuk ke siklus mikro. Siklus makro meliputi beberapa tahap yaitu:(Wijaya et al., 2019)

1. Feasibility analysis.

Tahap ini berhubungan dengan analisis area aplikasi potensial, mengidentifikasi sisi ekonomi dari pengambilan informasi dan disseminasi, membentuk studi keuntungan awal, menentukan kompleksitas data dan proses, mengatur prioritas aplikasi.

2. Requirement collection and analysis. Kebutuhan detail dikumpulkan dengan interaksi dengan pemakai potensial dan kelompok pemakai untuk mengidentifikasi permasalahan dan kebutuhan khusus. Ketergantungan aplikasi, komunikasi dan prosedur pelaporan diidentifikasi.

3. System design.

Tahap ini mempunyai dua aspek yaitu mendesain sistem basis data dan mendesain sistem aplikasi (program) yang menggunkaan dan memproses basis data.

4. Implementation.

Sistem informasi yang baru dibuat diimplementasi, basis data dibentuk dan transaksi basis data diimplementasikan dan diujicobakan.

5. Validation and acceptance testing. Tingkat akses dari sistem dalam memenuhi kebutuhan pemakai dan kriteria performansi divalidasi. Sistem diujicoba dengan kriteria performansi dan spesifikasi kelakuan.

6. Deployment, operation and maintenance.

Pada tahap ini dilakukan konversi pemakai dari sistem lama ke sistem baru melalui training. Tahap operasional mulai jika semua fungsi sistem dioperasikan dan divalidasi. Jika kebutuhan baru atau aplikasi bertambah, maka harus melalui semua tahap sebelumnya sampai semua divalidasi dan berhubungan dengan sistem. Monitoring performansi sistem dan pemeliharaan sistem merupakan aktifitas yang penting selama tahap operasi.

\section{Customer Relationship Management (CRM)}

Sistem Customer Relationship Management (CRM) adalah suatu sistem informasi lintas-fungsi yang ditujukan untuk mengintegrasikan dan mengotomasikan berbagai proses yang berorientasi pada pelanggan yang mencakup kegiatan pemasaran, penjualan, dan pelayanan kepada pelanggan(Randy, 2020)

Manajemen Hubungan Pelanggan (Customer Relationship Management disingkat CRM) adalah suatu jenis manajemen yang secara khusus membahas teori mengenai penanganan hubungan antara perusahaan dengan pelanggannya, dengan tujuan meningkatkan nilai perusahaan di mata para pelanggannya.

Menurut Lupiyoadi dalam Iriandini, dkk (2015), Customer Relationship Management (CRM) menekankan pada usaha menarik dan mempertahankan pelanggan melalui peningkatan hubungan perusahaan dengan pelangganya. Definisi lain mengungkapkan bahwa Customer Relationship Management (CRM) mengarah pada seluruh kegiatan pemasaran yang melakukan dengan tujuan 
Available online at http://jurnal.goretanpena.com/index.php/JSSR

untuk menstabilkan, mengembangkan serta memlihara pertukaran hubungan yang sukses. Dari beberapa pengertian di atas, CRM adalah sistem yang khusus untuk memanajemen hal-hal yang berhubungan dengan perusahaan dengan pelanggan.

\section{Fungsi-Fungsi dalam Customer Relationship Management (CRM)}

Sebuh sistem CRM harus bisa menjalankan fungsi:(Rahmawati et al., 2019)

1. Mengindentifikasi faktor-faktor yang penting bagi pelanggan;

2. Mengusung falsafah customeroriented (customer centric);

3. Mengadopsi pengukuran berdasarkan sudut pandang pelanggan;

4. Membangun proses ujung ke ujung dalam melayani pelanggan;

5. Menyediakan dukungan pelanggan yang sempurna;

6. Menangani keluhan/komplain pelanggan;

7. Mencatat dan mengikuti semua aspek dalam penjualan;

8. Membuat informasi holistik tentang informasi layanan dan penjualan dari pelanggan.

\section{Jenis-Jenis Customer Relationship Management (CRM)}

Dalam praktinya, CRM dapat dibedakan menjadi empat jenis, yaitu:

1. CRM operasional. $C R M$ operasional memiliki nilai bisnis yaitu:

a. Mendukung interaksi pelanggan dengan kenyamanan yang lebih besar melalui berbagai saluran, termasuk telepon, fax, email, chat, dan peranti bergerak.

b. Menyinkronisasi interaksi pelanggan di semua saluran.

c. Membuat perusahaan lebih mudah untuk menjalankan bisnis.

2. CRM analitis.

$C R M$ analitis memiliki nilai bisnis yaitu: a. Mengambil sejarah, kesukaan, dan informasi profitabilitas pelanggan secara lebih mendalam dari data warehouse dan database yang lain.

b. Memungkinkan analisis, prediksi, dan pemerolehan nilai dan perilaku pelanggan serta meramalkan permintaan.

c. Memungkinkan untuk mendekatkan pelanggan dengan informasi yang relevan dan menawarkan sesuatu yang dapat diatur sesuai kebutuhan.

3. CRM kolaboratif.

$C R M$ kolaboratif memiliki nilai bisnis yaitu:

a. Memudahkan kolaborasi dengan pelanggan, pemasok, dan mitra kerja.

b. Meningkatkan efisiensi dan integrasi melalui rantai pasokan.

c. Memungkinkan tanggapan yang lebih cepat terhadap kebutuhan pelanggan melalui penyediaan barang atau produk di luar perusahaan.

4. CRM berbasis portal.

$C R M$ berbasis portal memiliki nilai bisnis yaitu:

a. Menyediakan peranti dan informasi kepada semua pemakai yang sesuai dengan peran dan kesukaan masing-masing.

b. Memberdayakan semua pegawai untuk menanggapi permintaan pelanggan lebih cepat dan menjadi benar-benar fokus pada pelanggan.

Menyediakan kemampuan untuk mengakses, menghubungkan, dan menggunakan seluruh informasi pelanggan baik yang internal maupun eksternal secara seketika.

\section{HASIL DAN PEMBAHASAN}

\section{Entity Relationship Diagram (ERD)}

Adapun Entity Relationship

Diagram (ERD) pada proses penjualan 
Available online at http://jurnal.goretanpena.com/index.php/JSSR

pakaian di Toko Baju Azzahra adalah sebagai berikut:

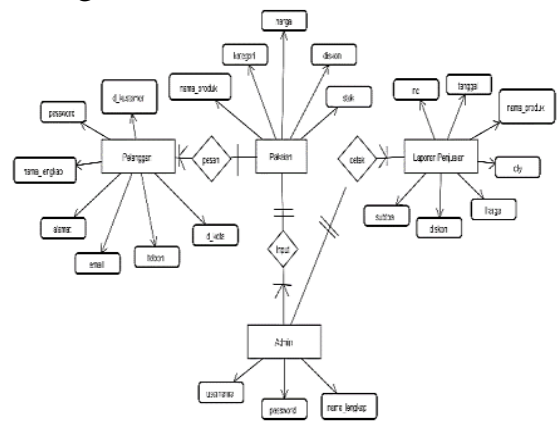

Gambar 1 Entity Relationship Diagram (ERD) Baru Sistem Penjualan Pakaian Pada Toko Baju Azzahra

\section{Pemodelan Berorientasi Objek Menggunakan Unified Modelling Language (UML) \\ Unifed Modelling Language} (UML) adalah salah satu standart bahasa yang banyak digunakan di dunia industri untuk mendefenisikan requirement, membuat analisis dan desain, serta menggambarkan arsitektur dalam pemrograman berorientasi objek. Berikut perancangan menggunakan $U M L$ :

\section{Use Case Diagram}

Use Case merupakan pemodelan untuk kelayakan (behavior) sistem informasi yang akan dibuat. Use Case mendeskripsikan sebuah interaksi antara satu atau lebih aktor dengan aplikasi sistem informasi penjualan pakaian pada Toko Baju Azzahra berbasis web .yang akan dibuat.

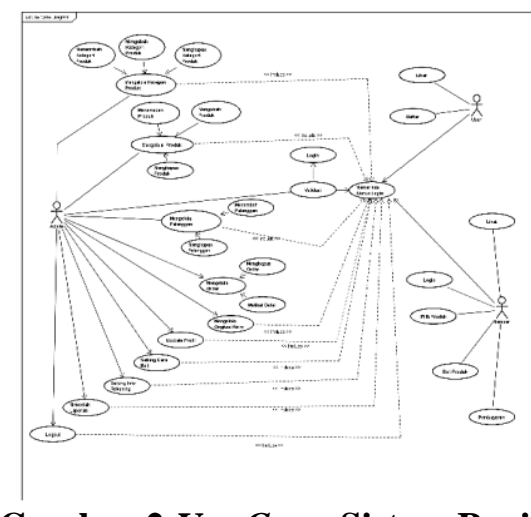

Gambar 2 Use Case Sistem Penjualan Pakaian Toko Baju Azzahra

\section{Class Diagram}

Diagram kelas atau Class Diagram menggambarkan struktur sistem dari segi pendefenisian kelas-kelas yang akan dibuat untuk membangun sistem.

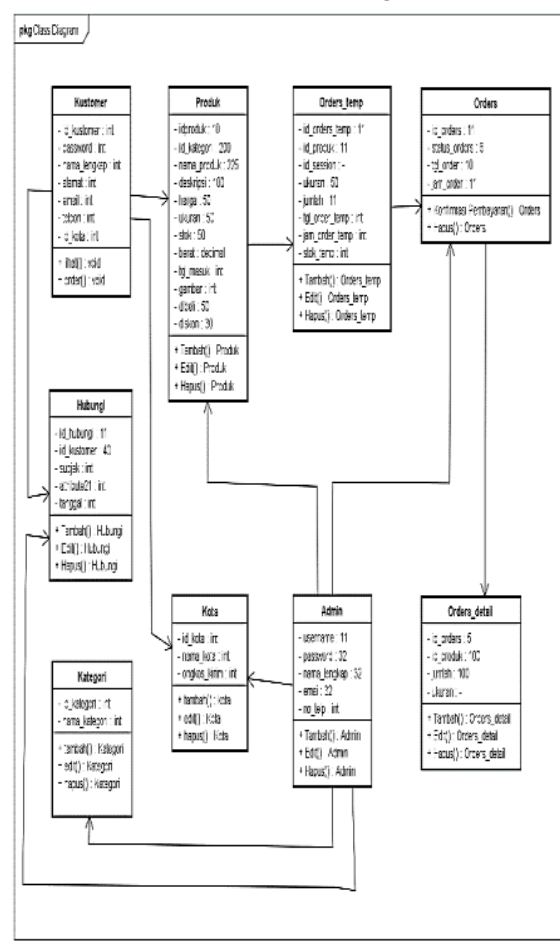

Gambar 3 Class Diagram Sistem

Penjualan Pakaian Pada Toko Baju Azzahra

\section{Sequence Diagram}

Diagram sekuen menggambarkan kelakuan objek pada use case dengan mendeskripsikan waktu objek dan message yang dikirimkan dan diterima antar objek. Oleh karena itu untuk menggambarkan diagram sekuen maka harus diketahui objek-objek yang terlibat dalam sebuah use case beserta metodemetode yang dimiliki kelas yang diinstansiasi menjadi objek itu.

Sequence Diagram Login

Admin (administrator) masuk ke halaman login admin terlebih dahulu untuk melakukan Login. Jikan username dan password benar maka admin akan masuk ke halaman menu utama. 
Available online at http://jurnal.goretanpena.com/index.php/JSSR

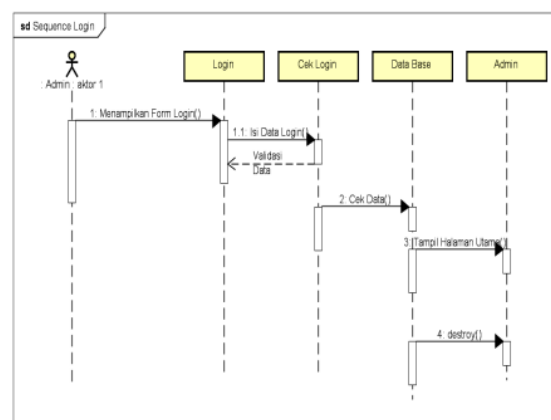

Gambar 3 Diagram Sequence-Login

\section{Sequence Diagram Logout}

Admin (administrator) masuk ke halaman utama admin terlebih dahulu untuk melakukan logout. Jika logout berhasil maka admin akan keluar dari halaman menu utama dan menonaktifkan semua menu yang ada di halaman utama

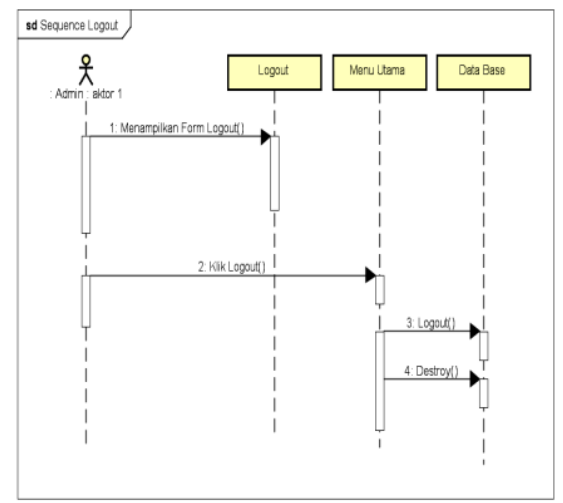

Gambar 4 Diagram Sequence untuk Logout

Sequence Diagram Data Produk

Setelah melakukan login, admin masuk ke halaman menu utama administrator dan memilih menu produk, kemudian admin menginputkan, mengubah serta mengedit data produk. Jika berhasil data akan langsung tersimpan kedalam database. Dari gambar diagram sekuen dibawah ini maka tahapan yang ada adalah sebagai berikut:

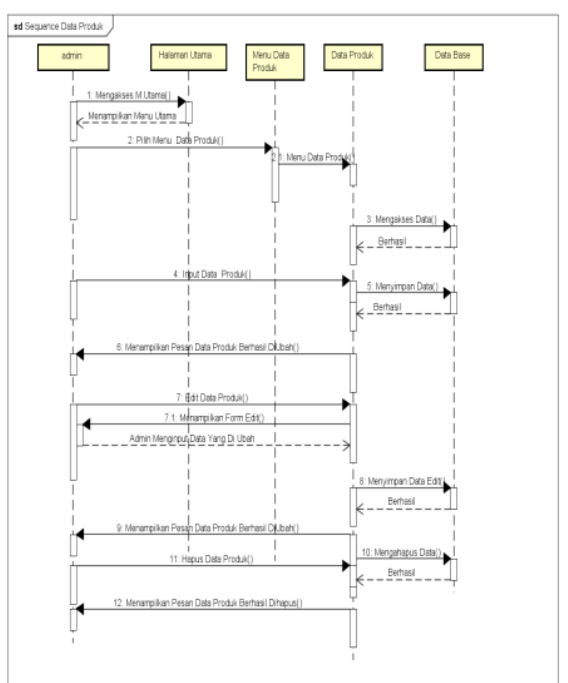

Gambar 5 Diagram Sequence untuk Menu Produk

Sequence Diagram Data Pelanggan

Setelah melakukan login, admin masuk ke halaman menu utama administrator dan memilih menu pelanggan, kemudian admin menginputkan, mengubah serta mengedit data pelanggan. Jika berhasil data akan langsung tersimpan kedalam database. Dari gambar diagram sekuen dibawah ini maka tahapan yang ada adalah sebagai berikut:

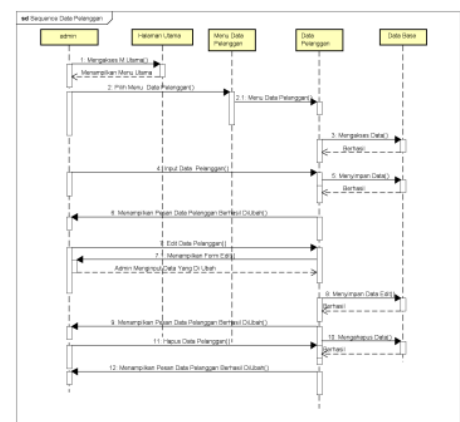

\section{Gambar 6 Diagram Sequence untuk Menu Pelanggan}

3. Sequence Diagram Data Laporan Setelah melakukan login, admin masuk ke halaman menu utama administrator dan memilih menu laporan, 
Available online at http://jurnal.goretanpena.com/index.php/JSSR

kemudian admin mencetak data laporan. Jika berhasil data akan langsung tersimpan kedalam database. Dari gambar diagram sekuen dibawah ini maka tahapan yang ada adalah sebagai berikut:

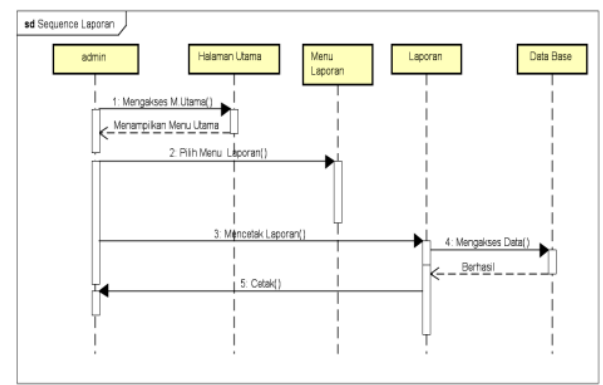

Gambar 7 Diagram Sequence untuk Menu Laporan

\section{Activity Diagram}

Diagram aktivitas menggambarkan workflow (aliran kerja) atau aktivitas dari sebuah sistem atau proses bisnis atau menu yang ada pada perangkat lunak. Berikut adalah gambar dari Activity Diagram dari sistem informasi penjualan pakaian pada Toko Baju Azzahra.

\section{Activity Diagram Login}

Admin (administrator) masuk ke halaman Login admin terlebih dahulu untuk melakukan login. Jika username dan password benar maka admin akan masuk ke halaman menu utama.

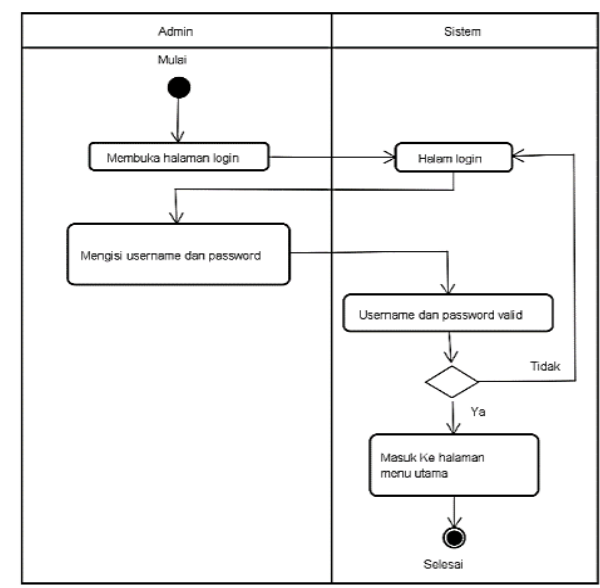

Gambar 8 Activity Diagram Login

\section{Activity Diagram Logout}

Admin masuk ke sistem, kemudian sistem menampilkan halaman menu utama kemudian admin melakukan logout.

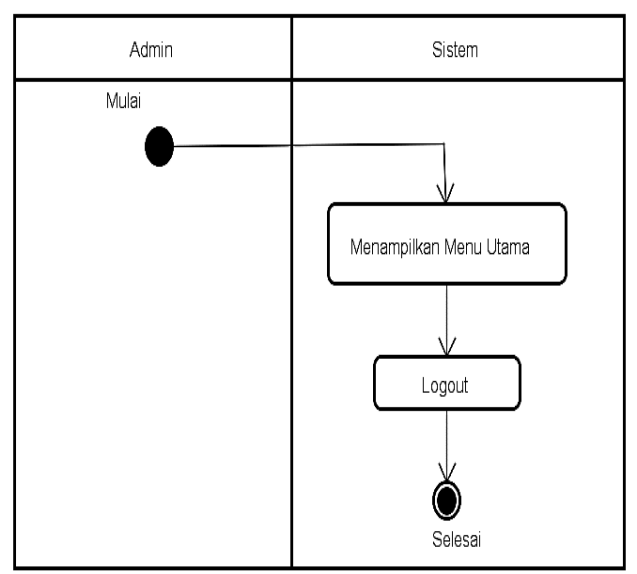

Gambar 9 Activity Diagram Logout

3. Activity Diagram Input Produk

Setelah admin melakukan login kemudian admin masuk ke halaman menu utama dan masuk ke form produk, setelah itu admin menginputkan data produk dan sistem secara otomatis akan menyimpan data tersebut ke dalam database.

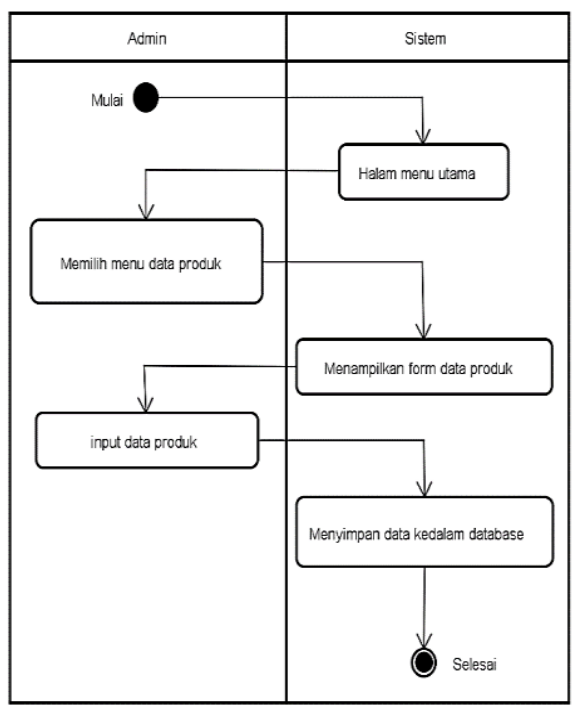

Gambar 10 Activity Diagram Input Produk 
Available online at http://jurnal.goretanpena.com/index.php/JSSR

\section{Activity Diagram Input Pelanggan}

Setelah admin melakukan login kemudian admin masuk ke halaman menu utama dan masuk ke form pelanggan, setelah itu admin menginputkan data pelanggan dan sistem secara otomatis akan menyimpan data tersebut ke dalam database.

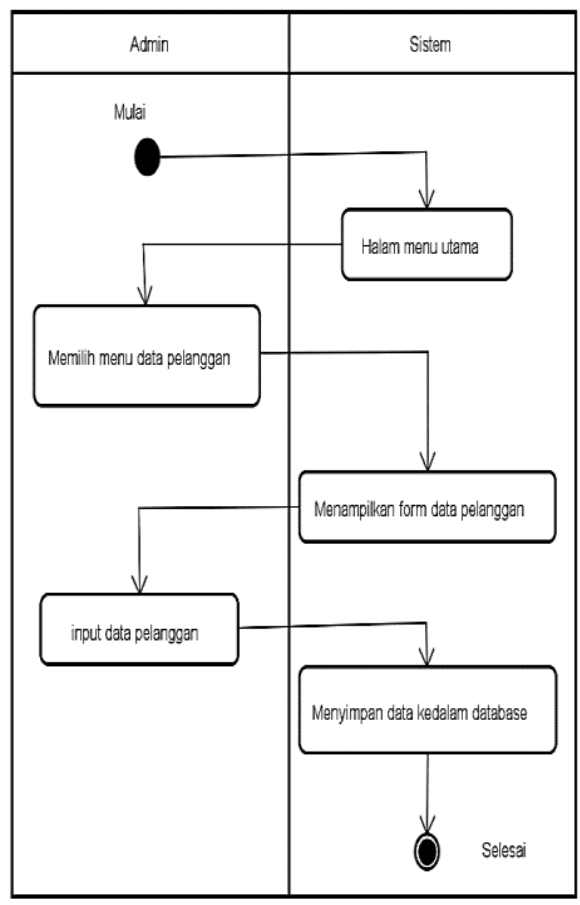

Gambar 12 Activity Diagram Input Pelanggan

\section{Deployment Diagram}

Diagram deployment atau deployment diagram menunjukkan konfigurasi komponen dalam proses eksekusi aplikasi. Diagram deployment juga dapat digunakan untuk memodelkan sistem client server ataupun sistem tambahan yang menggambarkan device, node serta hardware. Adapun diagram deployment sistem yang penulis rancang adalah sebagai berikut:

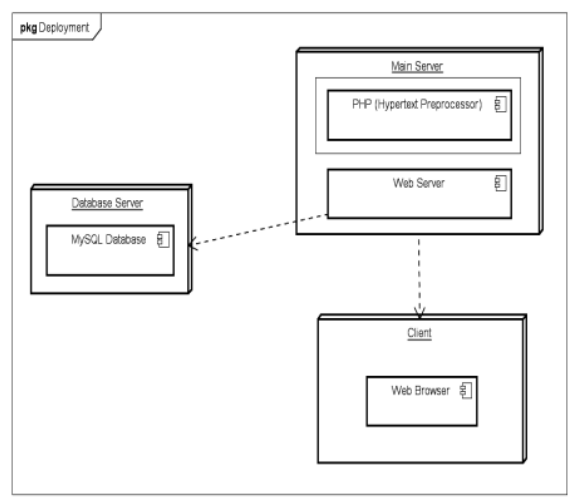

Gambar 11 Deployment Diagram Sistem Penjualan Pakaian Pada Toko Baju Azzahra

Hasil pengujian ini merupakan hasil tampilan program yang telah selesai dibuat. Berikut adalah hasil tampilan program Implementasi E-Commerce Penjualan Pakaian dengan Metode Customer Relationship Management pada Toko Baju Azzahra Berbasis Web.

\section{Tampilan Halaman Utama Web Toko Baju Azzahra}

Tampilan utama web Toko Baju Azzahra merupakan tampilan awal saat memasuki web program Toko Baju Azzahra. Berikut ini adalah gambar tampilan awal form menu utama halaman admin Toko Baju Azzahra.

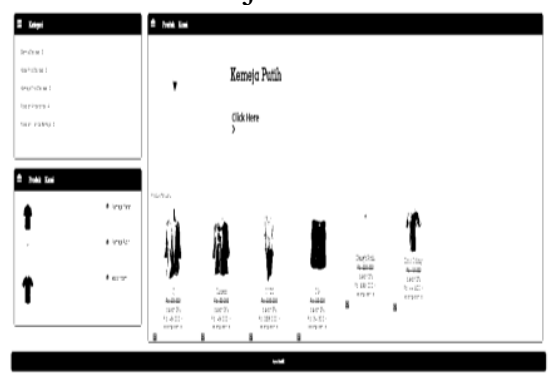

\section{Gambar 13 Tampilan Halaman Utama} Web Toko Baju Azzahra

Tampilan output laporan data penjualan, Berikut ini adalah tampilan output laporan data penjualan: 
Available online at http://jurnal.goretanpena.com/index.php/JSSR

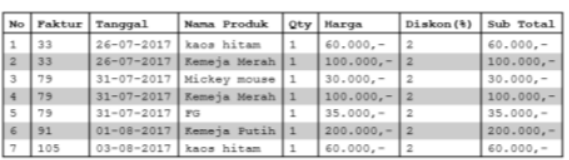

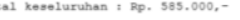

guelah yang torjual : ? unit

Gambar 14 Tampilan Output Laporan Data Penjualan Toko Baju Azzahra

\section{SIMPULAN}

Aktivitas Customer Relationship Management (CRM) dilakukan oleh Toko Baju Azzahra dengan berbagai macam alasan, yang paling utama ialah memperluas dalam pemasaran produk serta memperlancar penjualan. Alasan lainnya ialah mempertahankan serta menambah pelanggan baru sebagai mitra terpecaya.

Strategi Customer Relationship Management (CRM) juga dapat mempermudah Toko Baju Azzahra dalam merekap hasil laporan.

Beberapa saran yang diusulkan ialah

1. Sistem yang dibuat diharapkan bisa diterapkan dan sebaiknya harus bena-benar dikaji dan dipelajari secara mendalam, sehingga didapatkan kemudahan dalam menggunakan sistem baru.

2. Memaksimalkan penggunaan CRM guna memperoleh informasi tentang pelanggan dengan tujuan untuk meningkatkan mutu pelayanan.

\section{DAFTAR PUSTAKA}

Emaluta, F. H. K., Isnalita, I., \& Soewarno, N. (2019). The Effect of Customer Relationship Management (CRM) To Customers' Loyalty and Customers' Satisfaction as Mediator Variables. Jurnal AKSI
(Akuntansi Dan Sistem

Informasi), 4(2), 59-63. https://doi.org/10.32486/aksi.v4i2 .352

Guntur, budiyanto arief, \& Djasuro, S. (2017). PENGARUH KUALITAS PELAYANAN DAN CUSTOMER

RELATIONSHIP

MANAGEMENT TERHADAP LOYALITAS PELANGGAN DENGAN KEPUASAN PELANGGAN SEBAGAI Pendahuluan. Journal of Management.

Middleton, E. L. (2019). No Perasaan kesehatan tubuh utama di rumah tinggi indikator terkait kesehatan analisis struktur yang tersebar bersama Title. 2, 281-291.

Rahmawati, Y. O., Kusniawati, A., \& Setiawan, I. (2019). Pengaruh Customer Relationship Management dan Kualitas Pelayanan Terhadap Lotyalitas Konsumen Sepeda Motor Yamaha (Studi pada Konsumen Bahana Ciamis). Business Management and Entrepreneurship Journal, 1(4), 102-115.

Randy, M. F. (2020). Analisis Customer Relationship Management Terhadap Loyalitas Melalui Kepuasan Pelanggan Pt Pelabuhan Indonesia Iv (Persero) Makassar. AkMen JURNAL ILMIAH, 17(4), 590-598. https://doi.org/10.37476/akmen.v 17i4.1150

Ratnasari, D., Nursehah, I., Ghina, M. M., \& Yusuf, A. (2021). Pengaruh e-crm dan kepuasan pelanggan terhadap loyalitas pelanggan matahari departement store karawang The effect of $e$ - 
Available online at http://jurnal.goretanpena.com/index.php/JSSR

crm and customer satisfaction on customer loyalty of matahari department store karawang. 23(1), 164-171.

Riris Roisah, Iis Iskandar, Ridwan Mahanka, Andry Trijumansyah, \& Nita Yunita. (2019). Upaya Meningkatkan Loyalitas Pelanggan Melalui Customer Relationship Management. JURNAL ABDIMAS BSI Jurnal Pengabdian Kepada Masyarakat Vol. 2 No. 1 Februari 2019, Hal. 80-88, 2(1), 80-88.

Sholihah, N. A., \& Fahrullah, A. (2020). ( Crm ) on Muzakki Loyalty ( Case Study Yatim Mandiri Surabaya ). 5(2), 90-99.

Wijaya, E., Komara, A. H., \& Santoso, Pamuji Hari, W. (2019). Effect of Customer Relationship
Management and Service Quality in Efforts To Improve Satisfaction and Loyalty of Bank Central Asia Customers in Pekanbaru City. Jurnal Akuntansi ,Kewirausahaan Dan Bisnis, 4(2), 192-199.

Yuniar, N. F., \& Handriani, I. (2020). Sistem Customer Relationship Management untuk Perusahaan Penjualan Alat Komputer Menggunakan Analisis Fishbone. Teknika, 9(2), 129-137. https://doi.org/10.34148/teknika. v9i2.292 